\title{
Search for Social Identity in Parijat's Blue Mimosa
}

\author{
Dr. Ramesh Prasad Adhikary* \\ Lecturer (English) T. U. P.N. Campus, Pokhara
}

*Corresponding Author: Dr. Ramesh Prasad Adhikary, Lecturer (English) T. U. P.N. Campus, Pokhara

\begin{abstract}
Parijat, an existentialist feminist novelist, in her novel Blue Mimosa, presents a female protagonist, Sakambari who is in search for self and autonomy in the patriarchal society. Women, in the Panchayat system, or in whatever political systems were subjected and dominated by the males. It was necessary to break such system and ideology to emancipate women from the corrupted society. Sakambari has rebelled against the conservative male ideology. This novel is an attempt to introduce women's entity with their name with males to introduce them. The woman protagonist Sakambari involves herself in smoking and debating as a revolt against patriarchal society for the emancipation and selfhood of women.
\end{abstract}

Keywords: social identity, patriarchy, Feminism, Existentialism, freedom of choice, self

\section{INTRODUCTION}

Parijat was born in the Tea-Estate of Darjeeling in 1937 A.D as the daughter of Kalu Sing Waiba and Amrita Moktan. Her real name was Bishnu Kumari Waiba (Waiba is a subgroup of Tamang) but she wrote under the pen name Parijat (Parijat is a night-flowering fragrant jasmine flower). She has been hailed by her contemporaries as one of the most innovative and first modern novelist of Nepal. The themes and philosophical outlook of her poems, novels and stories are influenced by her Marxist and feminist views and her own personal circumstances. Parijat suffered from a partial paralysis since her youth and ventured from her home only rarely during the past twenty years. She was unmarried and childless; a status that was not usual for a woman in Nepalese society and that is due partly to her illness and partly, it seems due to personal preference. Despite her disability, Parijat is a formidable force in Nepali literature, and her flower-filled room in a house near Balaju has become a kind of shrine for progressive Nepali writers.

In 1966 her first novel, Blue Mimosa was published and received the Madan Puraskar, the only award offered in Nepal, for the best novel of the year. Critical response to the novel was of two kinds. On one side were those who said the philosophy of the novel was decadent, its substance vulgar and obscene, its theme foolishly imitative of the west. On the other side, were those who felt that Parijat brought Nepal into the world of modern literature. She overturns most of the expectations raised by previous novels. Her main characters are anything but ideal. Sakambari is skinny, she smokes, and she wears glasses. Her ideas about war and religion are iconoclastic; her ideas about sex are abnormal. Mujura, a less important and less interesting character, is the traditionally ideal woman who lowers her eyes when speaking to a man. Suyogbir Singh is not a typical hero. True, he is a Gurkha Warrior, but one whose memories, released by Sakambari's goading words are of guilt and misery. Their love affair is outlandish.

The differences in age, in temperament, in experience make union impossible, yet though the relationship is absurd, the pain and frustration are genuine. Even the setting of the novel gives only glimpses of the idyllic beauty of Nepal; it focuses instead on the unsettling life of the city. All traditional values are rejected because the world in which we find ourselves in Parijat's novel is not exclusively that of Hindu or Buddhist culture but the world of the alienated and the absurd.

The novel especially reminds us of Albert Camus and Sigmund Freud. It is the amalgation of existential and psychological issues which are juxtaposed. Parijat had found in them an affinity to her own feelings about life. But she maintains that the characters and situations described in her novel reflect, at least metaphorically, the life of Kathmandu. She sees life in Kathmandu as complex, difficult and frustrating. She portrays it as an empty, sterile place where meaningful life has come to a 
standstill and the motions of life go on as a matter of routine. The psychological background to the novel is Suyog's memories of his sexual exploitation of Burmese tribal women during his military service. His infatuation remains almost wholly unexpressed and Sakambari dies. In her death there is an underlying suspicion that Suyog's single clumsy attempt to reveal his feelings to her is in some way responsible.

Since the first publication of Parijat's Blue Mimosa (1965) numerous critics have expressed their opinions on the different aspects of the novel. Most of them have focused on the existential aspect as the main subject matter of the novel. In this regard Prof. Dr. Abhi Subedi comments in his book Nepali Literature: Background and History (1978) that Parijat, a modern Nepali writer follows an existential trend in her writings. Her novel Blue Mimosa establishes her to this stand which is completely based on existential philosophy. At the same time, he warns to Shankar Lamichhane, the preface writer of the book that he tends to take the novel sometimes out of its range.

The novel is different in its theme and characters than many other traditional novels. Sakambari, one of the characters, is compared with the archetypal woman. Despite her beauty she has an aura about her that attracts men towards her. Another character Suyogbir is compared with an agnostic Buddha. He had fought many battles and had slept with many women while he was on the front but none of them had left any impression on his mind. He falls in love with Sakambari who is an emaciated and mysterious lady. In contrary to Suyogbir's past experiences, Sakambari's death shatters him much. He does not see any meaning in his life.

Sandra Zeidenstein emphasizes on the uniqueness of the novel. According to her, this novel Blue Mimosa breaks the tradition of prose writing, which was established long ago in the history of Nepali literature. The hero and heroine are usually ideal in look but anything more. In different relationship, inhumanity, frustration, absurdity, lack of pure love and unhappiness are the major characteristics of the novel which overturns the trend of previous novels.

Therefore, it seems that critical reviews focus mostly to the single subject matter of the meaninglessness, uselessness of love, life etc. in the novel. Some of the articles published often in newspapers about Parijat and her novel Blue Mimosa have also given regularity to the same kind of critical responses. Aparajita Acharya can be taken as an instance.

\section{CONCEPT OF SOCIAL IDENTITY}

Peoples are suffered from social ostracism because they do not fit into the social norms of what it means to be able-bodied. Women's empowerment begins with het consciousness perception about herself and her rights, her capabilities and potential, awareness of her gender and social-cultural, economic forces that affect her. This study intends to address how the protagonist of the novel Blue Mimosa attempts to free herself from patriarchal boundaries by establishing herself and autonomy? And why Parijat's portrayal of Sakambari in the novel Blue Mimosa correlates with her ideas of the female as being equal in society?

For the most part, feminist theory has assumed that there is some social identity, understood through the category of women, who not only initiates feminist interests and goals within discourse, but constitutes the subject for whom political representation is pursued. But politics and representation are controversial terms. On the one hand, representation serves as the operative term within a political process that seeks to extend visibility and legitimacy to women as political subjects; on the other hand, representation is the normative function of a language which is said either to reveal or to distort what is assumed to be true about the category of women. For feminist theory, the development of a language that fully or adequately represents women has seemed necessary to foster the political visibility of women.

Recently, this prevailing conception of the relation between feminist theory and politics has come under challenge from within feminist discourse. The very subject of women is no longer understood in stable or abiding terms. There is great deal of material that not only questions the viability of 'the subject' as the ultimate candidate for representation or, indeed, liberation, but there is very little agreement after all on what it is that constitutes, or ought to constitute, the category of women. The domains of political and linguistic 'representation' set out in advance the criterion by which subjects themselves are formed, with the result that representation is extended only to what can be acknowledged as a subject. 
Foucault points out that juridical systems of power produce the subjects they subsequently come to represent (4). Juridical notions of power appear to regulate political life 'in purely negative terms that is through the limitation, prohibition, regulation, control and even 'protection' of individuals related to that political structure through the contingent and retractable operation of choice. But the subjects regulated by such structures are, by virtue of being subjected to them, formed, defined, and reproduced in accordance with the requirements of those structures. Judith Butler points out:

If this analysis is right, then the juridical formation of language and politics that represents women as "the subjects" of feminism is itself a discursive formation and effect of a given version of representational politics. And the feminist subject turns out to be discursively constituted by the very political system that is supposed to facilitate its emancipation. (4)

The political construction of the subject proceeds with certain legitimating and exclusionary aims, and these political operations are effectively concealed and naturalized by a political analysis that takes juridical structures as their foundation. Feminist critique ought to understand how the category of 'women', the subject of feminism is produced and restrained by the very structures of power through which emancipation is sought.

As Butler refers Denise Riley's title suggests, Am I that Name? is a question produced by the very possibility of the name's multiple significations. If one is a woman, that is surely not all one is; the term fails to be exhaustive, not because a pregendered 'person' transcends the specific paraphernalia of its gender, but because gender is not always constituted coherently or consistently in different historical contexts, and because gender intersects with racial, class, ethnic, sexual and regional modalities of discursively constituted identities. As a result, it becomes impossible to separate out 'gender' from the political and cultural intersections in which it is invariably produced and maintained.

To trace the political operations produce and conceal what qualifies as the juridical subject of feminism is precisely the task of a feminist genealogy of the category of women. In the course of this effort to question 'women' as the subject of feminism, the unproblematic invocation of that category may prove to preclude the possibility of feminism as a representational politics. The identity of the feminist subject ought not to be the foundation of feminist politics, if the formation of th - iubject takes place within a field of power regularly buried through the assertion of that foundati rhaps, paradoxically, 'representation' will be shown to make sense for feminism only when the subject of 'women' is nowhere presumed.

\section{ANALYSIS OF THE TEXT}

Parijat, an existentialist feminist novelist, in her novel Blue Mimosa, presents a female protagonist, Sakambari who is in search for self and autonomy in the patriarchal society. Women, in the Panchayat system, or in whatever political systems were subjected and dominated by the males. It was necessary to break such system and ideology to emancipate women from the corrupted society.

Sakambari, the protagonist of the novel Blue Mimosa, engages herself in verbal diatribe with males and shows her disregard to male dominated actions. This sort of doings shows the clear glimpse of debate as well as struggle by Sakambari for the freedom and emancipation from the male dominated world. She does not agree with the chauvinistic norms and values, which are restraints for the autonomous self for her. Defining feminists in terms of their work Maria Mies says, "Feminists are those who dare to break the conspiracy of silence about the oppressive, unequal man-woman relationship and who want to change it" (6). She talks in favour of women autonomy. For her autonomy is the feminist effort to maintain and recreate the innermost subjective human essence in women. The feminists claim to autonomy means a rejection of all tendencies to subsume the women's question and the women's movement under some other apparently more general theme or movement. Feminists are in search of a situation where there is no center, no hierarchy, no official and unified ideology and no formal leadership. There should be dynamism, diversity, as well as the truly humanistic environment.

The sense of difference has been felt by the female because of increasing self-awareness among women, changes in their relations with men, and desires to extend their social roles. Thus, these changes in consciousness led women to search their selfhood. There are always men when the time comes for in decision making. The participation of female in decision making is taken as valueless. 
Males make decisions about female's life themselves. The feminists are searching or fighting for their participation in decision making.

In the same case, Sakambari is an ideal girl with different attitudes and behaviours than other girls in the society. She also seeks her participation in decision making about her life. She is an obstinate, enigmatic, jealous and self-emphatic character. She wants to live and die only for her sake on her own way by keeping away from love and marriage. She rejects marriage as for her it is a kind of chain of patriarchal domination upon female. She does not like to be interrupted and praised by others, especially males. Her ideas about war and religion are iconoclastic. She smokes and wears glasses. Her opinion of sex is aberrant. She presents herself boldly to her brother and other male characters as well. Suyog's love affair with her and her unwillingness to submit herself to male desires suggests a revolutionary idea. The protagonist dares to overcome the male chauvinism and establishes her life style of sophistication to give a sense of feminity. She likes the life without the presence of male. She gets everything sufficient in her life. More than this she has freedom and individuality in this life. She can handle her life as she wishes. There lies her autonomous existence. In short, Sakambari is a revolutionary girl who tries to establish her own independent self and consolidate herself identity.

Before entering into the text for interpretation of the novel Blue Mimosa, it is relevant to tell something about relational self. Because it is necessary to unravel about the relational self in which how does it work in regard to the female protagonist, Sakambari with other characters in the text. In this regard it is noteworthy to take the ideas from the women writers of the Romantic era, where they conceptualized the self in a very different way. Dorothy Wordsworth imaged the female self as 'a floating island' in which she tried to show the relationship as circulation by relating the ideas of 'water and air', 'food, safety, shelter' to birds and plants and 'to fertilize some other ground'. By embracing the ideas of self of Romantic women writers, modern feminist psychologist Nancy Chodorow in The Reproduction of Mothering called a relational self instead of female self. This self has no firm ego boundaries, and experiences its place in the world as and entanglement in shifting relationship, with family members, friends, lovers and co-workers. By sharing this feminine sense of the self as relational, John Keats described it: 'the poetical character itself . . is not itself - it has no self - it is everything and nothing -' (letter to Richard Woodhouse, 27 October, 1818).

The door of the events opens with the reference of the third meeting of narrator with Shivaraj in the bar who is taking Suyogveer to his home towards Bishalnagar. Suyogveer sees a compound encircled by mimosa trees when he reaches there. Shivaraj introduces his sister Sakambari, 24-year-old girl with thin body. She also seems strange in nature. This sort of entrance of the main character is one of the purpose of Parijat to depict her unique character to question to the general expectation of the patriarchal norms and values should be in any female characters of that society. In this very context, about Sakambari, her dresses, way of behave, way of walking, her structures, the narrator vomits:

... I saw a woman of twenty six. Unnoticed by my friend, I studied her colouring her clothes, her height and weight, her expression, the way she walked, everything. In her white sari and sleeveless white blouse, with her long hair loose, she could not be called an ugly woman. Noticing us she glanced our way and then, without curiosity, walked towards the well. (1)

At this point Parijat has presented her character in a different way that is a unique manner, which is opposite to traditional norms and values. Her clothing, colouring, height, weight, expression and ways of behave has been presented in a unique form from the beginning part of the novel Blue Mimosa. It seems that by seeing Sakambari's own way of dealing, Suyogveer is in confused. In our traditional manner, wearing a white sari and blouse and keep hair loose has been taken as not good. Because this type of wearing is used by a widow in the society which is taken in negative way, in the so-called male-rooted society.

Here, Parijat has presented the female protagonist in the bold and boyish manner where she does not feel shame like a traditional woman. She presents her as boy and does what a boy can do, whatever, whenever and wherever the matter is. It does not affect her. She likes to live her life in her own style. She wants to create her own 'self'. She presents her in this manner and says, "My name is Sakambari" (3). This expression gives the clear picture of 'boyish' and 'bold' behave of Sakambari which helps to create her an independent self and consolidates herself identity by challenging the preexisted social rule and regulations that have kept women under domination and prejudices for a long times. 
Suyogveer does not keep him silent while Sakambari abruptly appears nearby. By becoming startled, he speaks:

"My name is Sakambari." Her voice burst in on us like a bullet. Startled, I turned toward the door and saw a woman of twenty-four. She was about five-feet-three, fair, with very large breasts on an extremely thin body. She wore gold-rimmed glasses on deep-set sparkling black eyes. Her hair was cut very close to her head, in the style of ancient Hebrew soldiers, and her small, white lobes wore earrings of black stones. (3)

From the above expression, here, Parijat tries to create a world of life style from the side of female with the help of the female protagonist, Sakambari in the novel Blue Mimosa. We can see here, Sakambari's way of wearing ornaments, glasses on deep-set, her style of cutting hair very close to her head that means very short-cut hair like a boy's style and style of wearing earrings are totally different. This message shows that Sakambari's unique manner and extraordinary behaviours which are very opposite to traditional lifestyle, norms and values. These all clarify that Sakambari does not like to be subjected and dominated by the patriarchal society rather she wants to create and establish her own lifestyle of sophistication to give a sense of feminity. In short, Sakambari presents herself as a revolutionary girl by wearing distinct dresses and ornaments which are supposed to be unsuited to the preexisted society. So, she creates her own different self identity equals to males.

It is noteworthy to indicate and give short glance on the contrasts between Sakambari and Mujura. In this way, it can be understood through this expression:

Now I've done it! I've got to go. Bari won't be asleep. If she finds out about this, she'll explode. [.. . ]. She's asleep by now. Bari does not get to sleep until close to midnight. Besides, it's not Mujura's nature to oppose anyone. She doesn't complain if I drink. But Bari doesn't care what people think; she gets angry. And that makes me care for her even more. (10)

From the above expression by Shivaraj, Parijat shows the contrasts between Sakambari and Mujura, where Majura is presented as a traditional girl who does not oppose anyone, she does not complain if Shivaraj drinks. She lowers her head when speaking with male characters. On the other hand, Sakambari does just opposite to Mujura. She does not care what people think; she gets angry when her brother drinks. It means she overlaps the male power as Shivaraj represents. All these clues show that Sakamari plays the important 'boyish role' in the novel to control male characters. Her role seems more dominant and superior to male character to show her separate autonomous self towards the male-rooted society. "She was not the kind of woman who immediately feels helpless" (12). She is a bold woman who does not feel any hesitation to speak with anyone.

Sakambari is that sort of bold and courageous lady, who can make to feel serious and startled Suyogveer, an ex-army and her brother Shivaraj too. She speaks as if she is commanding a soldier or someone else without any hesitation. This kind of way of behave or way of talking makes Suyogveer to call her a bold woman:

What a bold woman. She must be to call her brother Shiva. When I paid no attention to her words, she spoke again. "Didn't you hear me?" Then, pretending to be surprised, I said, "No I was just wondering where these orchids that are hanging on the wall come from. I haven't seen them anywhere else around here." (12-13)

How far Sakambari is bold and strict lady, it is clarified through the above extract, and gives that sort of sense of behave of Sakambari.

Parijat has uniquely presented the female protagonist as if she has the capacity of resistance. Sakambari as a protagonist who resists and gives the bitter and short cut answers to the questions of male characters. In this context the narration is relevant from the side of Suyogveer has been extracted here:

... I asked, "If the bees can't settle here, what's the use of this flower?" [. . .]. But she didn't treat it as commonplace. Blowing the cigarette smoke from her mouth, she said, "The flower won't be spoiled; it is secure." (14)

It is the metaphoric description of life of Sakambari who compares her with a mimosa flower and Suyogveer with a bumblebee. It is said that mimosa flower falls with a single touch or kiss of a 
bumblebee in metaphoric sense that is the relationship between Bari and Suyogveer. Whatever it is does not affect in Bari's personality. She wants not to settle the bees on the flower because it buds for itself and opens for itself. It falls for only for itself. It falls by its own will. This is the encounter of Bari with the male characters. By revealing Bari's philosophy about life, Parijat has attempted to create her own norms and values about life distinct from the traditional norms. Sakambari said:

"If a flower buds for itself and opens for itself and, as if accepting some compulsion, falls whether it fights the black-bee or not, then why should it fall suffering the sting of the black-bee? It falls only for itself. It falls by its own will." (14)

The expression of Bari gives the clear cut sense of her philosophy about life. Metaphorically Sakambari says that she does not need any help from male and she is herself lonely sufficient for living. She can live her life without the presence of a male partner who has been doing suppression and domination upon female for a long time. In nutshell, she does not like to be interrupted by especially males. She wants to live and die only for her sake on her own way. This type of philosophy of life helps her to enhance a process to create an autonomous self-hood for her and women in general. Bari describes about the flower as a life-killing will and it can fade and fall by its own will which is meaningful and truth in its own position. This kind of indirect expression is her effort to define the cultural, social and intellectual space of the life by reconstructing a new kind of social norm.

Not only that even in the context of love too, Bari defines that one can live a complete life without being in mutual love. "It is love, that's all, love. And there is no inevitability about love either or about suffering in love. It is possible to live out one's life alone . . . alone" (15). So her concept of love, life, marriage etc. all are in a kind of static and challenging form to the contemporary social system, rules and regulations etc. Parijat is trying to question upon the social and cultural definition of life, love and death to create her intellectual space. In every step she is focusing in the life style of Sakambari who wants to fight with the social system of life in the contemporary society. In another words, through this example Parijat is trying to construct her cultural, social and intellectual space within the existing norms of the society in rebellious form.

The manner of talking of Bari is like a boy does which is taken as normal in the society whatever he does normal in the society whatever he does behave with the people. Similarly, she does not hesitate to speak. She just says whatever comes into her head. She does not care how much she embarrasses someone. In this context the narrator said:

I thought, she just says whatever comes into her head. She does not care how much she embarrasses someone. She is really an outspoken woman. How easily she calls me first 'soldier' and then 'old man'. I think she even embarrasses her brother a bit. (17)

In this way, Bari is presenting her 'boyish' behaviour. She does not discriminate whether man or woman, whatever it is. She does equal behave to all equally. In every manner of her activities, we can see 'boyish' performative role which seems very superior and dominant towards the male characters that makes them to be helpless and cool in front of the female character especially Bari. So Bari plays a dominant performative role with her manner of burst talking in the novel Blue Mimosa.

Sakambari not only challenges to the social norms and values but she also hates and questions to the 'Present Giving and Receiving' system of the society which is under the male rule and regulations. The following extract is relevant and Shivaraj says, "The day after tomorrow is Bari's birthday. You're invited. Please don't bring anything like a present when you come. Bari doesn't accept that sort of thing. She'd be likely to throw it back in your face" (22).

The concept of Bari about the cultural values and norms has been presented by Parijat in different way by challenging to the preexisting system of the society. Parijat questions even to the present giving and receiving system of the society during that period. When Suyogveer is invited for the birthday party of Bari, Shivaraj requests not to bring any kind of presents because Bari hates it and she may throw it back to his face. She says that it is the traditional cultural concept related to patriarchy or created by it. It is another example of Bari's revolutionary as well as unique behaves through which Parijat attacks over the so-called civilized norms of the society.

On the occasions of the celebration of her birthday party, Bari puts question marks in regard to wishing for living which has been traditionally followed that she does not like to accept. It is noteworthy to understand through this expression: 
Sakambari stood at the side of the couch lighting a cigarette. Opening a bottle, Shivaraj said, "Long live Bari. May her birthday come often?" "May Bari grow old! That is Shiva's wish", cried Bari. I felt her mockery. Shiva objected. "That doesn't mean 'grow old,' it means 'live for many yours'." (26)

In the same way, when there is the discussion of old age, Bari views that there is no any meaning of being old and she wishes to die in time. This means she objects Shiva's wishes for her long living. Her interpretation of living and dying is also based upon her own philosophy. By rejecting her brother Shiva's wishes, in return she says, "What's the use of living? Why live to be old? Shiva, you don't know how to bless; you should say, 'Die in time.' What is there that is really worth living for?" (26) At this point Parijat is creating her own space in the society about the meaning of living, being old and dying, being in different than that of the societal concept. According to her there is no any effect in living and dying as the society takes it. Bari would like to be defined as whatever other say it does not affect to her. This shows Bari's resistance towards male norms and values that helps her to be different from others. To be different is to be a rebellious. That is why it is a kind of tool which she uses it as a weapon to fight for emancipation and autonomous self.

When the subject matter of war comes Parijat defines it as a crime. For whatever reason one may define the war as meaningful and significant but overall it is a crime. Parijat's this concept can be understood through Bari's expression:

"War is a crime, Shiva. The war we fight in someone's name, under someone's orders, is a crime committed by one individual against another. Every killer ought to write his crime on his forehead. It isn't always apparent on the surface." (27)

So Parijat is trying to create her own norm in terms of war too. People might have shown their glorious achievement through war. But Parijat shows her ant-war concept. She says that it is a kind of crime, for whatever reason we might fight. It is useless.

Parijat is intending to depict the enigmatic character of Sakambari here. She does not look happy in regard to be called by her pet name although most women are pleased and happy to be called by their pet name, because to be called by women with pet name is a traditional way of male system. It has been a kind of chain to sublimate and dominate women which keeps women in passive position and commodifies them as things for satisfaction of male desires. The way of calling with pet name, women have been kept under the shadow of silence, passivity by so-called civilized males. They are deprived of their own self identity, freedom and rights from the primitive era. It has been killing the intellectual capacities of women for a long time due to their unawareness in thinking and doing. So it seems that Bari is not infavour of pet name. This can be understood through this expression of Suyogveer:

There was no change in Bari.It was difficult to see the look in her eyes behind the glasses sparkling from the electric light. Most women are pleased and happy to be called by their pet name, but Bari did not look as if she were. Casually, she said, "you may call me whatever you like." (27)

In this regard, because of the concept of Parijat on pet name, she has tried to construct her own norm in the favour of women by questioning to the contemporary societal system. So Bari is presented in this manner who does not like to be called by her pet name, because it has been used by the so-called intellectual males to keep women under the shadow of submissive position. It seems that she is guided by her own-truth to create herself identity.

The seventh part of the novel starts with the reference of Suyogveer's waiting to Shiva raj being in Shiva's living-room. At that time Suyogveer sees Bari, living flat on her back on the green grass. Bari comes near to him when she sees to Suyog and says that she was on her way to the temple with her mother. Suyog asks her if she believes in God. During that time Bari's definition of God, temple and her belief is also different than that of the contemporary society's concept. Parijat wants to define god and its existence through her own way. She is indifferent about the existence of god. And at the same time, she does not have a good opinion of man either. She believes on "idea god" rather than the "god". Parijat, in regard to the sins done by human beings, says that man should have the power of understanding about the god because washing away one's sins before the idea of god is completely meaningless. It is just foolishness. 
The $9^{\text {th }}$ part starts with Suyogveer's efforts of forgetting to Bari by touching the insect-killing orchids after the departure of Bari towards Terai. After a month Bari returns. She appears with her long hair. It had grown long enough to cover her ears and neck. Suyog requests her to let it be long. But Bari behaves oppositely. The expression is as Suyogveer vomits:

I like long hair on women, so one day I said to her, "Bari, long hair really suits you. You should let it grow." When I went there three days later, she was waiting with an inch of hair. She was like a widow who had come from hardware with a shaven head or a madwoman who had just cut her hair. (48)

It is Bari's way of behave. Her behave of cutting long hair into short, her dressing, wearing glasses, smoking cigarettes, manner of speaking, all of these show the performative behaviours and manners of Sakambari. These activities are so distinct and extraordinary to the male characters and others. Because Suyogveer represents the patriarchy who likes only traditionally accepted norms and values, where Bari's performative activities to him seem odd and unacceptable. That's why Bari's way of living is distinct than the others. She is living for herself and want to do according to her own will rather than other's wish. Through this example too Parijat is focusing to give the new way of life in context of Bari.

Similarly, when there is the reference of Sanu's elopement, Shivaraj feels being insulted for some days in the society because his sister did not follow the social rule of marriage. Mujura and his mother resolve on compromise. Mujura says that if they care for each other no one can do anything about it. They will be able to settle down and build a life. Sanu was not a girl of bad character. But Bari does not take much interest on it and simply reacts and forgets it soon. When Shivaraj asked Bari, she merely said, "An impulsive girl. What a hurry she was in to get married" (49). It is another example of Bari who is not more serious and strict-follower of the social rules and regulations. Bari rejects marriage and for her it is a kind of chain of patriarchal domination upon female. So, after all Bari fights with the social norms all the time to create her own identity in the society.

In the $11^{\text {th }}, 12^{\text {th }}$ and $13^{\text {th }}$ chapters the narrator turns towards his history. He remembers his past in Kachin Village of Makhring in Burma, where he has committed three serious crimes during the Second World War. They are raping a Chin girl, head-hunter's daughter, his remembrance of orchids that bloom in the Burmese forest in relation to the Matinchi whose virginity has been used by him and raping a Kachin girl, a buffalo-herding girl. These all activities show the hidden nature of so-called civilized and intellectual men. If we talk about the nature of man which has been accepted as so-called civilized. Whatever a man does whether barbaric or criminal that is taken as usual by the society on the contrary, when a woman does something little wrong that is not acceptable. Thus, Suyogveer is presented as a representation of patriarchy according to Parijat. So he presents his activities that are not dissimilar from any notorious criminal. His barbarism causes him to commit lots of murdering and rape that proves him as a rude in the human personality in the society. He shows his beast nature. He rapes and enjoys with Kachin girl's body and finally she dies due to his barbarous hands.

Parijat presents Shivaraj as a member of the patriarchal society who wants to create the good image in the society by marrying Bari with an educated and cultivated man of the society. But Bari rejects and challenges his interest where she takes marriage as a chain of domination by males upon females. His interest can be clear through this expression:

In our talk that day, Shiva said that he was going to keep Bari at home this year. Then he would send her to college since she was so bright. After she had passed her B.A. he would think of marrying her. He was looking for someone who was educated and very cultivated. (73)

Shivaraj is wishing to marry with an educated and very cultivated man and wants to give the continuation to the contemporary social norms. But Bari breaks the social male rules and norms by keeping away her from love and marriage because she wants to live and die only for her sake on her own way to create her autonomous and independent self.

The fifteenth part is the climax part of the novel Blue Mimosa. During this period, Bari, to whom Suyogveer had kissed her soft lips, holding of her white neck where she didn't move even an inch. Bari does not react rather she remains silent. To be remain silent is a kind of opposition from her side. She indirectly rejects the unacceptable activity which has been unexpectedly done by Suyogveer upon 
her. That has made her strong to be rebellious because if there is no any suppressive activity done upon someone who can't be rebellious and can't resist. He or she can be only passive by following and accepting anything happens upon her or him. When Bari remains as silent that challenges Suyogveer where he afraid of Bari due to his activity.

Bari falls sick day by day but does not leave eating. This shows that Bari plays the silent per formative role being rebellious towards male. This silent behaviour makes startled to Suyogveer and other characters as well. Suyogveea remembers Bari's concept of life in this context that "why a flower should fall suffering the sting of the black-bee. It falls only for itself. It falls by its own will" (88-89). At the same time, Parijat is trying to reflect the concept of life of Bari who never wants to be sublimated by males. Rather she wants to live and die for her individual sake, that carries her at the point of departure of life for death which becomes helpful to shape her independent and autonomous self that can make her distinct from others. Here Parijat is trying to create the static new kind of status by taking the base of Bari's life and her philosophy about life.

To be remained unmarried is unacceptable according to the so-called civilized male dominated social norms and values. It is a kind of old and traditional blind concept which has been followed by all the members of the society to keep women under the power and domination of males. It has been taken as a means to commodify women to fulfill their desires since the primitive era of human civilization. Thus, it is Bari, the protagonist of the novel Blue Mimosa who breaks and rejects this type of the socalled chauvinistic societal norms and rules. Instead, she creates her own norms and values in order to establish her own 'female self' which is independent and autonomous in search of identity of women in general.

It could be understood that Suyog's single kiss did not affect her life and death because she has been remained unmarried and childless by rejecting marriage where she has run her motion of life to death. Without being sublimated and dominated by male wish and desires. Rather she has presented her 'like a boy' which proves her bold, boyish and unique behaviours. So, Parijat has presented Bari as a rebellious warrior, where Suyogveer, Shivaraj and other characters are in victimized form. Bari is that sort of individual who has successfully created her intellectual and social norms in the novel Blue Mimosa. It is not only Bari but as a whole Prijat's project is to create her own social and intellectual norms and concept. In nutshell, Parijat has uniquely constructed her own distinct norms by challenging to the so-called fittedness of social norms of contemporary time. She has crossed the attitudinal barriers of social norms with her bold and unique characters.

Thus, it can be said that through the image of the bold, strict and courageous lady protagonist, Sakambari who by challenging and disregarding male norms and dominated actions, she has been able to create her distinct autonomous and independent self. Lastly Parijat, the novelist, is advocating the female self in general in the novel Blue Mimosa.

\section{CONCLUSION}

Though the novel has been analyzed and interpreted in different perspectives, but this research analyzes how the protagonist of the novel Blue Mimosa attempts to free herself from patriarchal boundaries by establishing herself and autonomy. The original background of this novel is the Panchayat period. Women were dominated and oppressed by the patriarchal society. Thus, Parijat has written this novel to emancipate women from the discriminatory social rules and regulations. The protagonist, Sakambari is fighting for women's freedom and selfhood. Social rules and regulations as women should only involve them in the household works. It was restricted for women to involve in outward and extra activities. Sakambari has rebelled against the conservative male ideology. This novel is an attempt to introduce women's entity with their name with males to introduce them. The woman protagonist Sakambari involves herself in smoking and debating as a revolt against patriarchal society for the emancipation and selfhood of women.

Parijat in this novel seems to be against women's dependence on men because such dependence defeats the very purpose of meaningful life. Sakambari rejects any marriage proposal, as marriage for her is a boundage for women's life. Sakambri's play with smoke, wearing glasses, sitting on the ground of an open garden surrounded by mimosa trees are her boyish qualities which prove that she is not less in any sector than males.

Sakambari raises the feminist voice for freedom from male domination. She has shown masculine qualities to show equality among all. She is so determined in her aim that she never surrenders before 
males. She rejects the decision made by Shivaraj and Suyogveer seeking her participation in decision making. So they cannot force her to follow their decision directly. Sakambari's death becomes a great shock in Shiva's and Suyog's life whose accompaniment she was. After her death they felt loneliness and frustration. This shows the necessity of women in the society in regard to equality in different sectors. Thus, instead of following the patriarchal rules and regulations living there, she struggles further to get freedom and self. Parijat is a woman with full understanding of women's status and their power in society. So, Parijat herself can be taken as a feminist writer. That is why her portrayal of Sakambari in the novel Blue Mimosa correlates with her ideas of the female as being equal in society. Thus, we can conclude that Parijat has demonstrated Sakambari as a conscious, bold, courageous and rebellious woman who fights for women's rights against patriarchy. Her courageous and bold behaviour help her to challenge the patriarchal society and get victory over it in order to attain the autonomous and independent self.

\section{REFERENCES}

[1] Acharya, Aparajita. "Parijat in Shreerish Ko Phool". The Kathmandu Post. Jan. 6, 2008:5.

[2] Atam, Netra and Krishna Hari Baral. Upanyas Siddhanth Ra Nepali Upanyas. Kathmandu: Sajha Prakashan, 2056.

[3] Butler, Judith. Gender Trouble: Feminism and the Subversion of Identity. Ed. Linda J. Nicholson. New York: Routledge, 1990.

[4] Chapagain, Ninu and Khagendra Sangraula. Parijat Smirti Grantha. Kathmandu: Parijat Smirti Kendra, 2051.

[5] Gautam, Shreedhar. "Parijat and Blue Mimosa." The Kathmandu Post. Feb. 17, 2005:4.

[6] Hutt, Michael James. Nepali: A National Language and its Literature. New Delhi: Sterling Publishers, 1998. 214-15.

[7] Kreidl, Ingrid. "Parijat-A Writer of the People". Parijat Smirti Grantha. Kathmandu: Parijat Smirti Kendra, 1994.

[8] Lamichhane, Shankar: Preface. Shirishko Phool. Kathmandu: Sajha Prakashan, 1965.

[9] Parijat. Shirishko Phool. Kathmandu: Sajha Prakashan, 1965.

[10] Pradhan, Kumar. A History of Nepali Literature. New Delhi: Sahitya Academy, 1984.

[11] Stovling, Britta. "The Influence of Humanity in Blue Mimosa." Parijat Smirti Grantha. Kathmandu: Parijat Smirti Kendra, 1994.

[12] Subedi, Abhi. Nepali Literature: Background and History. Kathmandu: Sajha $\quad$ Prakashan,1978. 12021.

[13] Zeidenstein, Sondra. "Introduction." Blue Mimosa. Trans. Tank Vilas Varya. Kathmandu: Joshi Printing Press, 1972.

AUTHOR'S BIOGRAPHY

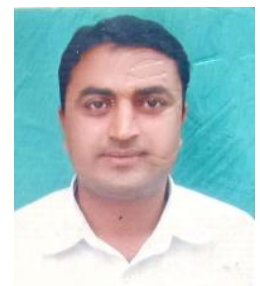

Dr. Ramesh Prasad Adhikary has been working as an Assistant Professor of English, at Tribhuwan University, Kathmandu (Nepal) for 10 years. He has completed his PhD from SNU in Existential Philosophy; and has contributed more than 30 scholarly research articles in the international journals. 19 books have been published by him related to English language, literature and literary theories. His core research interest is in literary theories and cultural study.

Citation: Dr. Ramesh Prasad Adhikary. Search for Social Identity in Parijat's Blue Mimosa "International Journal on Studies in English Language and Literature (IJSELL), vol 8, no. 2, 2020, pp. 23-32. doi: http://dx.doi.org/10.20431/2347-3134.0802003.

Copyright: (c) 2020 Authors. This is an open-access article distributed under the terms of the Creative Commons Attribution License, which permits unrestricted use, distribution, and reproduction in any medium, provided the original author and source are credited. 